\title{
Education Services for Special Intelligent and Talent Children in Elementary School
}

\author{
Liza Murniviyanti', Asep Supena
}

DOI: 10.35445/alishlah.v13i3.1320

\begin{abstract}
Article Info
Abstract

Keywords: Children;

Education;

Intelligent;

Special;

Talent

Special intelligent children and special talents require special treatment and handling in education. This study describes the educational services for special intelligent children and special talents at Baptist Elementary School Palembang. This study used a qualitative method with a field research approach. Data collection techniques were observation, interviews, recording and documentation. The data source used the primary data source because the researchers took the data directly in the field, namely Elementary School Baptist Palembang. Respondents in this study were 8 people who were 1 person as the head of Palembang Baptist Elementary School, 2 accompanying teachers for special intelligent and special talent children, and 5 students categorized as special intelligent children and special talents. The findings obtained are 1) educational services for special intelligent children and special talents at Baptist Elementary School Palembang. 2) Factors inhibiting and supporting the learning process of special intelligent children and special talents at Baptist Elementary School Palembang. 3) The teacher's strategy in dealing with special intelligent children and special talents at Palembang Baptist Elementary School.
\end{abstract}

Kata kunci:

Anak-anak;

Pendidikan;

Cerdas;

Istimewa;

Bakat

\begin{abstract}
Abstrak
Anak cerdas istimewa dan bakat istimewa membutuhkan perlakuan dan penanganan khusus dalam dunia pendidikan. Penelitian ini bertujuan untuk mendeskripsikan tentang layanan pendidikan anak cerdas istimewa dan bakat istimewa di SD Baptis Palembang. Penelitian ini menggunakan metode kualitatif dengan pendekatan penelitian lapangan. Teknik pengumpulan data dilakukan melalui observasi, wawancara, rekaman dan dokumentasi. Sumber data yang digunakan adalah sumber data primer karena peneliti mengambil secara langsung data di lapangan yaitu SD Baptis Palembang. Responden dalam penelitian ini sebanyak 8 orang. 1 orang selaku kepala SD Baptis Palembang, 2 orang guru pendamping anak Cerdas Istimewa dan Bakat Istimewa dan 5 orang siswa yang dikategorikan anak cerdas istimewa dan bakat istimewa. Hasil penemuan yang diperoleh adalah 1) proses layanan pendidikan untuk anak cerdas istimewa dan bakat istimewa di SD Baptis Palembang. 2) Faktor penghambat dan pendukung proses pembelajaran anak cerdas istimewa dan bakat istimewa di SD Baptis Palembang. 3) Strategi guru dalam mengatasi anak cerdas istimewa dan bakat istimewa di SD Baptis Palembang.
\end{abstract}

\footnotetext{
${ }^{1}$ Universitas Negeri Jakarta, Jakarta, Indonesia

Email: murniviyantiliza@gmail.com

${ }^{2}$ Universitas Negeri Jakarta, Jakarta, Indonesia

Email: asepsupena@unj.ac.id
}

Vol.13 (3) December, 2021

Received: November 13, 2021; Received in revised form: November 21, 2021; Accepted: December 12, 2021; Available online: December 31, 2021. This is an open access article under a Creative Commons Attribution-NonCommercial-ShareAlike 4.0 International License. 


\section{INTRODUCTION}

Each child possesses a unique advantage; one of the advantages children possess is an IQ that is above average. Children with an IQ greater than this average are special intelligent children and possess unique talents. They require special education services. Education services discuss the broad efforts made to alter human behaviour in order to preserve continuity and improve a child's quality of life. It is one of the long-term strategic programs that is constantly in need of improvement and quality improvement that should be carried out proactively, intensively, and strategically rather than reactively. Children with exceptional intelligence and abilities require close supervision from both parents and teachers.

One of the educational service programs that support special intelligence and talented children is accelerating the field of learning materials in schools by using high-level questions. The material acceleration program in the classroom is one form of education program for special intelligence and talented children implemented in schools. Providing educational provisions under the intelligence potential and special talents of students, this program provides opportunities for them to complete regular programs in a shorter time to graduate earlier than their friends. The purpose of implementing the acceleration program is to fulfil the human rights of students according to their own educational needs, to meet the needs of students who have special characteristics in terms of cognitive and affective development, this is by Law Number 20 of the 1945 Education system of 2003 Article 5 paragraph 4 concerning citizens with the potential for special intelligence are entitled to special education. Also, according to the 1988 Outlines of the State Policy, it is said that specially gifted students need special attention to develop their abilities by their personal development.

In Indonesia, the term gifted is known as special intelligence and special talents. The terms special intelligence and talent were first introduced by the 2003 National Education System Law and find it in article 32 (1) which reads "Extraordinary Education is education for students who have difficulty in learning, because of the difficulty to participate in the learning process. "Emotional, psychological, social disorders or have the potential to have special intelligence and talents". In the National Education System Law, Number 20 of 2003, articles 27 and 28 stipulates that family education is one of the educational pathways recognized as an educational path for children. The purpose of this statement is that education does not only take place in schools. Parents must work with schools and communities as a complete set of pedagogical pillars. They must complement each other in carrying out the educational process.

The study related to children with special intelligence and talent is always interesting. They must be facilitated according to the talent they already have. The school environment must be conducive so that they can achieve optimal performance (Ummai, 2017). Everyone has different talents and abilities, so different education is also needed. One of them is students with special needs, who need an education system that is different from other students in general. One of the children who need to be considered is a special intelligent child and special talent. Smart Special Talents (SST), often known as Gifted students, are classified as students with special needs (Nurul Chairiah et al., 2020). SST students need special treatment and handling in the world of education. Some of the reasons for special intelligence and talented children are students with special needs with intelligence levels above average, have high productivity reasoning and are responsible for their obligations, and have a great drive to get the achievement. While his personality characteristics have great curiosity, interest in challenges, not being easily satisfied and active in trying. Gifted children also have three basic human traits that unite the bond: general abilities with above-average ability, high commitment to tasks and high creativity (Murti et al., 2017), and different characteristics from children (Khairun Nisa et al., 2018). Therefore, in addition to services to support intelligence and talent, they need counselling and assistance to strengthen their social-emotional side (Irvan, 2020; Fitriana, 2015) because their mentality also has a different concept from ordinary children (Cook et al., 2020). 
Several previous studies showed that special intelligence and talented children have very different abilities from children in general. They need different services according to their needs. Therefore, this research is oriented to analysing the concept of educational services for special and gifted intelligent children according to the students' background and life. This concept is a different value proposed in research to provide different insights or perceptions about gifted and special intelligent children. So, the purpose of this study was to find out the educational services for special intelligence and talented children at Baptist Elementary School Palembang. The results of the research are also expected to provide input for elementary schools as a form of guidance in providing services to special and gifted intelligent children because these services will greatly affect their future. Moreover, education is part of developing their intelligence and talents.

\section{METHOD}

This research was conducted at Elementary School Baptist PalembangThis study used a qualitative method with a field research approach. It examined the various phenomena of educational services provided to elementary school students who have special talents and intelligence. In this case, the research analyzes the phenomenon of field data according to the concept of the research context (Creswell, 2012). Data collection techniques were carried out through observation, interviews, recordings and documentation. The data source used the primary data source because the researchers took the data directly in the field, namely Elementary School Baptist Palembang. Respondents in this study were 8 people, namely 1 headmaster of Elementary School Baptist Palembang, 2 teachers for special intelligence and talent children and 5 students who were categorized as special intelligence and talent children. The process of data analysis used the Miles and Huberman model through the process of data reduction, data presentation, drawing conclusions and triangulation (Miles \& Huberman, 1994).

\section{FINDINGS AND DISCUSSION}

The interviews concluded, namely 1) the process of educational services for special intelligence and talented children at Elementary School Baptist Palembang. 2) Factors inhibiting and supporting the learning process of special intelligence and talent children at Elementary School Baptist Palembang. 3) The teacher's strategy in dealing with special intelligence and talented children at Elementary School Baptist Palembang.

\section{The Education Service Process for Specially Intelligent and Talented Children at Elementary School Baptist Palembang}

In the usual schooling model, students are taught to think coherently, linear and convergent way. On the other hand, gifted children have simultaneous, global and divergent thinking models. This different way of thinking causes gifted children to be unable to adjust to children in general. This inability to adjust will ultimately make gifted children experience pressure, difficulty concentrating, behave differently, which will result in disturbances in achievement. Not even infrequently because of their difficulty to concentrate, gifted children are often diagnosed with concentration disorders because their behaviour is also diagnosed with hyperactivity. With his gifted abilities, a child often experiences unexpected things in the process of interacting with his peers (Idrus, 2013).

Based on the results of interviews with the head of Elementary School Baptist Palembang, and tutors for special intelligent children and special talents. Data obtained that 5 students are categorized as special intelligent children and special talents. This can be seen from the learning activities and learning outcomes at school. Schools are still implementing online and offline learning in the current learning process. The method used for special intelligent children and special talents is the teacher provides enrichment questions that are different from ordinary children. This special intelligent, and talented child at Elementary School Baptist Palembang is given additional hours 
outside of school learning. The material taught for special intelligent children and special talents at Elementary School Baptist Palembang is Mathematics and Natural Sciences lessons carried out directly in schools or accompanying teachers assigned by the principal directly come to the homes of special intelligent and special talents students.

The curriculum that applies to children like this is the same as applicable. The media used in learning are laptops, power points, google forms, classrooms and other IT-based media. This refers to the opinion expressed by Haryanto and Pujaningsih, namely the deepening method of providing learning that allows a more in-depth investigation of the field of study. Activities that can be carried out are in the form of ICT-based learning, learning centres, independent learning contracts, mentoring, field of study competitions, and resource-based learning (Haryanto \& Pujaningsih, 2008). In evaluating the learning of special intelligent children and special talents, the teacher assesses attitudes and skills with the task of making learning videos and working on questions orally and in writing. The form of Lesson Plan for special intelligent children and special talents is implemented by blended learning. Education services for special intelligent children and special talents provided by teachers, namely teachers, are trying to spend time for students outside of online learning hours by contacting the students concerned to do additional learning in oral form. If this extra hour is done offline in class, the teacher asks students to come to school to discuss questions that are much more difficult than the questions that exist during school hours. The questions used by the teacher are included in $\mathrm{C}_{4}, \mathrm{C}_{5}$ and $\mathrm{C} 6$. This means that the level of difficulty of the questions given to these special intelligent and special talent children is high. From the evaluation of the teacher's learning, it can be seen that there are students who are special intelligent and special talents in Elementary School Baptist Palembang. Based on the data obtained, some students have taken an IQ test with 130 results which can be categorized as special intelligent children and special talents.

The educational services provided by the teacher for special intelligent and special talent children at this Elementary School Baptist Palembang are very good. The principal holds a program to identify special intelligent children and special talents with mentor teachers in their fields. The school principal offers the children to take extracurricular which the school specially funds. In addition, on student learning outcomes, the teacher observes the abilities possessed by students. So that when there is a competition, students who have more abilities are sent to take part in the competition. Education services at Elementary School Baptist Palembang have achieved success. This is evidenced by students' many achievements in both academic and non-academic fields. Based on the interview data obtained, this special intelligent and special talent student at Palembang Baptist Elementary School has won the national level competition.

\section{Inhibiting and Supporting Factors in the Learning Process of Specially Intelligent and Talented Children at Elementary School Baptist Palembang}

Based on data from interviews that have been carried out directly with supervising teachers for special intelligent and talented children, namely with Mrs Nora Fransiska and Mr Berlin. The inhibiting factor is the difficulty of special intelligent and talented children to adapt and communicate with their classmates. While the supporting factor is the teacher must spend more time to provide lessons or questions that are more challenging for children like this. Meanwhile, according to the second informant, namely $\mathrm{Mr} \mathrm{Br}$, the inhibiting factor in the learning process of special intelligent and talented children is when providing online learning materials, there is less than optimal interaction between teachers and students so that additional learning is often carried out at students' homes if their parents agree. So, in this case, the teacher directly goes to the field to learn at home for children categorized as special intelligent and talented children. In contrast, the supporting facts are the motivation and direct support by the principal and accompanying teachers to provide study time outside of school hours. So that later there will be a competition, students like this are included. 


\section{Teacher's Strategy in Overcoming Special Intelligent and Talented Children at Elementary School Baptist Palembang}

According to data gathered from observations and interviews, strategies for dealing with children with exceptional intelligence and talent, such as the teacher providing special training assistance, were developed. A zigzag seating strategy is used in the classroom by the teacher. The principal supported this program, so the principal issued a Decree for teachers to accompany special intelligent and talented students. Specially gifted and talented children receive additional instruction after school, where they are able to address more complex issues. For example, if the student is in class $\mathrm{V}$, the material provided is class VI material.

The next strategy is if this learning is carried out not in schools, then the teachers who have been assigned directly will carry out this additional learning in the homes of special intelligent and talented children. It is carried out to prepare for the competition in the future. In addition, the teacher also gives several HOTS-based questions to determine the student's level of intelligence by looking at the learning outcomes.

Special education services for special intelligent and talented children can be in the form of enrichment and additional learning at school or at home. Efforts to help gifted children learn more effectively can be done by grouping special children in the form of enrichment. The form of the acceleration process is in the form of providing opportunities for the preparation of special curriculum designs. Special intelligent and talented children have problems that they often face, namely critical thinking skills that can lead to scepticism towards themselves and others, creative abilities and interest in doing new things that can make them dislike or get bored easily with their daily work. Children's desire to be independent in their studies and work and their need for freedom can lead to conflict because they cannot easily adapt or give in to pressure from their parents, school, or friends. A person's talent can be seen or reviewed from various aspects, both aspects related to his intelligence ability (IQ), his attitude displays as well as his psychomotor aspects. This can be used as a basis and study material in developing and providing better special education services so that they can develop optimally according to their potential (Ilyas, 2019).

According to Milgram, gifted children are divided into 4 categories. The first category is general intellectual ability. It is associated with thinking abstractly and solving problems logically and systematically. This ability is measured by analysis of performance test results and IQ test scores. The second category is specific intellectual ability, which means intellectual ability in one field, for example, in the fields of mathematics, language, music and science. The third category is general/creative thinking which is a process in problem-solving with unusual problem-solving. The fourth category is specific creative talent. This category focuses more on children's creative abilities that are more specific (Rohali \& Wahab, 2019).

Variations in the forms of acceleration for special intelligent and gifted children are 1) Early Admission (early entry) 2) Advanced Placement (accelerating the time for grade promotion). 3) Advance Courses (accelerating lessons), concurrent classes and other ways to accelerate the learning progress of supernormal children (gifted children). Emotion characteristics for gifted or special intelligent children are sensitivity, showing an unusual style of joking or humour and being sensitive to something that is not felt by others. Has a deep feeling for things and is sensitive to small changes in the environment (sound, smell, light). He naturally has a deeper sincerity than other children. Characteristics of special intelligent and gifted children are as follows

1. The ability of general intelligence is very high. This can be seen using intelligence tests (IQ).

2. Have special talents in certain fields.

3. High creativity in thinking and always come up with brilliant ideas.

4. The ability to lead is to direct and influence others to act as stated.

5. Have special achievements in the arts or other fields.

6. High-performance standards (perfectionist). 
7. Social development and emotional adjustment are above average (although some gifted children have difficulty adjusting because they have different abilities from their peers) (PSIBK, 2019)

Identifying intelligent and special gifted children is the development of traits or characteristics that have been found. Thus it is expected to facilitate the discovery and placement of intelligent and special gifted children. This is very helpful in determining the educational needs of intelligent and gifted children. Identifying intelligent and special gifted children is not an easy thing. The screening stage that must be carried out in identifying smart children and special talents involves several parties, such as teachers, parents, and the students concerned themselves. The assessment stage is related to the ability of general intelligence, scholastic talent and training talent, as well as the level of creativity and commitment to the task. The assessment is carried out using standardized tests and instruments, including intelligence tests, creativity tests, and the Task Commitment scale. The term gifted children in Indonesian is gifted children, extraordinary children and genius children. The intelligence levels of these gifted children are moderate gifted = IQ $130-140$, highly gifted = IQ $140-150$ and Genius = IQ > 150 (Nurhastuti, 2014).

According to Gagne, the factors of special intelligent children and special talents are that environmental catalysts facilitate or inhibit the talent development process; however, he did not provide a specific number of relevant causal factors (Wagner, 2021). A meta-analysis found an overall lower prevalence of depression among gifted adolescents and no significant differences between gifted and non-gifted groups for anxiety symptoms or suicidal tendencies (Cook et al., 2020). This means that gifted children have the lowest prevalence of depression, and there is no significant difference between gifted and gifted children in tendencies and anxiety symptoms.

\section{CONCLUSION}

The result of the analysis can be concluded that special intelligence and talents children have an IQ above the average of 130. The categories of special intelligent children and special talents have general intellectual abilities, special intelligent children and special talents having intellectual abilities in one field, problem-solving and high creativity. From the study results, it was found that there were 5 students with special intelligence and special talents at Baptist Elementary School in Palembang, accompanied by each teacher who had been assigned directly by the principal. In this study, from the interviews, data were obtained, namely 1) the process of educational services for special intelligent children and special talents at Baptist Elementary School Palembang. 2) Factors inhibiting and supporting the learning process of special intelligent children and special talents at Baptist Elementary School Palembang. 3) The teacher's strategy in dealing with special intelligent children and special talents at Palembang Baptist Elementary School.

\section{REFERENCES}

Cook, F., Hippmann, D., \& Omerovic, E. (2020). The sleep and mental health of gifted children: A prospective, longitudinal, community cohort study. Https://Doi.Org/10.1080/15332276.2020.1758977, 35(1), 16-26. https://doi.org/10.1080/15332276.2020.1758977

Creswell, J. W. (2012). Research, educational planning, conducting, and evaluating quantitative and qualitative research. Pearson Education.

Fitriana, D. (2015). Individu Berbakat (Giftedness): Tinjauan Psikologi Pendidikan. Al-Qalb : Jurnal Psikologi Islam, 6(1), 53-61. https://doi.org/10.15548/ALQALB.V6I1.813

Haryanto, \& Pujaningsih. (2008). Pelayanan Pendidikan Anak Berbakat Intelektual di Sekolah Dasar. KONVENSI NASIONAL PENDIDIKAN INDONESIA VI, 14.

Idrus, M. (2013). Layanan Pendidikan Bagi Anak Gifted. PSIKOPEDAGOGIA Jurnal Bimbingan Dan Konseling, 2(2), 116-131. https://doi.org/10.12928/PSIKOPEDAGOGIA.V2I2.2579

Ilyas, Z. (2019). Pendidikan Khusus dan Anak Berbakat. Hijri, 8(1), 47-62. http://jurnal.uinsu.ac.id/index.php/hijri/article/view/5782

Irvan, M. (2020). Urgensi Identifikasi dan Asesmen Anak Berkebutuhan Khusus Usia Dini. Jurnal 
http://journal2.um.ac.id/index.php/jo/article/view/16385

Khairun Nisa, Mambela, S., \& Badiah, L. I. (2018). Karakteristik dan kebutuhan anak berkebutuhan khusus. Jurnal Abadimas Adi Buana, 2(1), 33-40. https://doi.org/10.36456/ABADIMAS.V2.I1.A1632

Miles, M. B., \& Huberman, A. M. (1994). Qualitative Data Analysis; An Expanded Sourcebook. Sage Publication.

Murti, H., Haryanto, S., Penelitian, J., \& Pendidikan, E. (2017). Evaluasi keberhasilan pelaksanaan program kelas inklusi bakat istimewa (BI) seni tari. Wiyata Dharma: Jurnal Penelitian Dan Evaluasi Pendidikan, 5(2), 55-67. https://doi.org/10.30738/WD.V5I2.3375

Nurhastuti, N. (2014). Identifikasi Anak Cerdas dan Berbakat Istimewa. Seminar Nasional Pendidikan Luar Biasa Pemberdayaan Anak Berkebutuhan Khusus Dalam Menyonsong Generasi Emas.

Nurul Chairiah, M., Eti Rohaeti, E., Fatimah, S., \& Studi Bimbingan dan Konseling, P. (2020). Pengambilan Keputusan Karier Siswa Cerdas Istimewa Bakat Istimewa (CIBI). FOKUS (Kajian $\begin{array}{llll}\text { Bimbingan \& Konseling Dalam Pendidikan), } & 3(2), & 72-79 .\end{array}$ https://journal.ikipsiliwangi.ac.id/index.php/fokus/article/view/5040

PSIBK. (2019). Mengenal Seorang Gifted. Pustaka Pelajar.

Rohali, A., \& Wahab, R. (2019). Pemilihan karier berdasarkan gaya belajar model "Kolb" pada siswa cerdas istimewa kelas 12 cerdas istimewa bakat istimewa SMAN 1 Wonosari. JPK (Jurnal Pendidikan Khusus), 15(1), 9-16. https://doi.org/10.21831/JPK.V15I1.24434

Ummai, F. V. (2017). Anak berbakat dan dunia pendidikan. SCHOULID: Indonesian Journal of School Counseling, 2(2), 1-5. https://doi.org/10.23916/o8437011

Wagner, G. (2021). How group composition affects gifted students: theory and evidence from school effectiveness studies. Gifted and Talented International. https://doi.org/10.1080/15332276.2021.1951145 
Al- Ishlah: Jurnal Pendidikan, December 2021, 13 (3), Pages 2481-2488

Liza Murniviyanti, Asep Supena

This page is intentionally left blank 